\title{
INITIATING A PERMANENT ELECTORAL BODY TO RESOLVE DIGNIFIED ELECTION DISPUTES: ASSESSING THE EFFECTIVENESS OF GAKKUMDU
}

\author{
Fitria Esfandiari ${ }^{1}$, Sholahuddin Al-Fatih ${ }^{2}$ \\ 1.2Faculty of Law, University of Muhammadiyah Malang \\ Email: sholahuddin.alfath@gmail.com
}

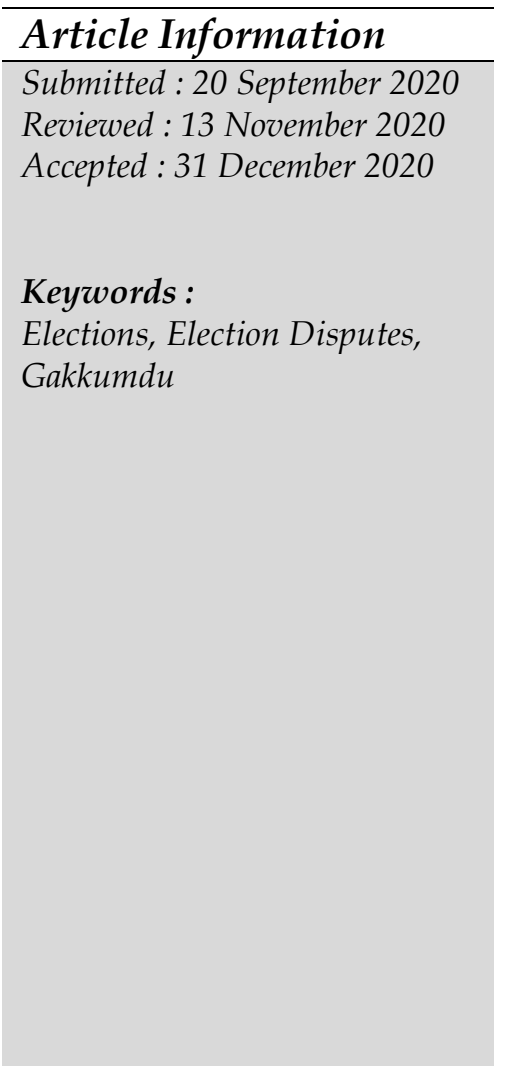

\begin{tabular}{l} 
Abstract \\
\hline This study aimed to evaluate ineffectiveness in the process of \\
resolving electoral disputes through Gakkumdu in simultaneous \\
elections in 2019. However, in practice there are difficulties in \\
handling the consequences of criminal norms and technical rules \\
which are not clearly formulated, causing differences of opinion in \\
resolving election disputes. The approach method used by the \\
author with normative juridical approach method (legal Research) \\
through literature study using primary legal data namely Law \\
Number 7 of 2017 on Elections, KPU Regulation and Court \\
Decision related to elections. Secondary data, especially library \\
materials containing information about election dispute problems \\
through Gakkumdu. The collection oflegal materials is carried out \\
by tracing the library in the form of information about the \\
evaluation of gakkumdu's role in resolving the dispute of the 2019 \\
Elections and in analysis using the method of descriptive analysis. \\
The results of this study concluded that Gakkumdu which is an \\
organ formed based on the mandate of Law Number 7 of 2017 on \\
Elections, has not worked optimally. It is very vulnerable to \\
overlap of authority between Bawaslu, The Police and the \\
Prosecutor's Office. On the other hand, this organ has the \\
opportunity to reduce the authority and independence of Bawaslu, \\
which has been supervising the elections. The combination of the \\
three institutions organically and substantive has not been able to \\
parse the dispute of the 2019 elections.
\end{tabular}

\section{Introduction}

Indonesia first held elections in 1955 (Al-Fatih, 2019). The 1955 elections were held in 2 stages, namely to elect members of the House of Representatives held on September 29, 1955 and to elect members of the Constituent Assembly held on December 15, 1955. The first elections were successfully held safely, smoothly, honestly and fairly and very (Soedarsono, 2006). However, the sweet history of the inaugural elections could not be continued in the next period of elections. This is because the next election is prone to be ridden by political 
interests, used as a formality event alone and cause many electoral disputes. Including the implementation of elections in the post-reform era (Fatih, 2020)

IDEA releases, there are at least 15 elements that must be fulfilled in order for an Election to be categorized as a democratic (Surbakti, 2011) : (1) structuring the legal framework; (2) the electoral system:(3) boundary delimitation, districting or defining boundaries of electoral units:(4) the right to vote and to be elected; (5) electoral management bodies; (6) voter registration and voter registers; (7) ballot access for political parties and candidates; (8) democratic electoral campaigns; (9) media access and freedom of expression; (10) campaigns finance and expenditure; (11) balloting; (12) votes counting and tabulating; (13) role of the representatives of the parties and candidates; (14) electoral observers; and (15) compliance and enforcement of electoral law.

These 15 elements, become a necessity, including clarity on the legal norms of elections. If 15 elements can be fulfilled, then an Election can be called democratic. Nevertheless, elections in Indonesia still must work hard to meet these 15 elements. especially regarding the legal norms of elections, where there are still many election disputes that cannot be resolved by law. In general, election disputes are divided into 3, (Surbakti, 2011) :

(1) disputes in the electoral process, both before and during the Election (especially those that occur between election participants or between candidates); (2) dispute or dispute of election results (Hereinafter abbreviated to PHPU); Dan (3) disputes of participants or candidates who object to the determination of The Electoral Commission (Hereinafter referred to to Komisi Pemilihan Umum or $K P U)$ and (Regional General Election Commission (hereinafter referred to Komisi Pemilihan Umum Daerah or KPUD).

Based on data collected from the Constitutional Court's website, since the 2004 elections, there has been a spike in PHPU disputes. PHPU cases in the 2004 elections there were 274 cases. Meanwhile, in the 2009 elections, there were 657 cases of PHPU. Details: for the DPR/DPRD level there are 627 cases, DPD level 27 cases, and the level of the presidential election there are 2 cases. That number rose in the 2014 General Election. The Constitutional Court in the 2014 elections received a total of 902 PHPU applications. A total of 866 cases in the People's Representative Council (Hereinafter named to DPR or Regional People's Representative Assembly (hereinafter referred to DPRD), 34 cases in the Regional Representative Council (hereinafter referred to DPD), and one case at the presidential election level. The number is relatively decreasing in the 2019 elections which only amounted to 340 cases of PHPU. This figure is down by 562 cases compared to the General Election in 2014. For DPR/DPRD level disputes, the Constitutional Court received 329 cases. At the DPD level there are 10 cases and the presidential election (Hadya Jayani, 2019).

The decrease in the number of election disputes in 2019 is indeed worth appreciating. Through several new policies, the government succeeded in limiting the number of PHPU complaints and Election disputes. However, this does not necessarily make the 2019 elections can be called as the most democratic elections, because there are still many gaps and disputes that occur in the community and have not found a solution. Because, when viewed in terms of electoral crimes, the 2019 elections resulted in more cases when compared to the Election in 2014.

Referencing data from the Indonesia Legal Roundtable (ILR) which published the results of research on the enforcement of electoral criminal law in the 2019 elections. One of 
its findings is that of the 348 criminal cases that have obtained the legal force of in-kracht, only 13 cases related to the Presidential Election (hereinafter referred to Pilpres). The remaining 335 cases are related to the Legislative Election (hereinafter referred to Pileg) (Salabi, 2019). The number of electoral criminal cases increased from 2014 with 203 cases of The Presidential Election and Pileg (Aziz Hakim, 2011). The case does not include cases that occur in the community but is not reported to integrated law enforcement (Gakkumdu; consisting of Bawaslu, Polri and Prosecutors). Throughout the 2019 elections, Gakkumdu was the most highlighted unit in terms of handling election disputes.

To strengthen this research, the author uses several theoretical foundations such as: Theory of Election Effectiveness and Democratic Election Theory. The theory of electoral effectiveness provides a theoretical basis for collective behavior that points to the accuracy of production, quality, efficiency and flexibility in achieving the level of electoral goals (Nazir, 2017). While the theory of democratic elections mentions that an election can be said to be democratic if the election can be a moment for rotate of power, recruitment conducted openly and the realization of a public accountability (Liando, 2016). Both theories are used to measure whether Gakkumdu has played a role in accordance with his auth, especially to realize democratic elections.

From the title and the basis of the theory, the author will limit the discussion of this research to analyze the problem related to election disputes in the 2019 elections and to elaborate the concept of relevant integrated law enforcement agencies to resolve election disputes.

\section{Research Methods}

The approach method used by the authors in this study is the Normative Juridical approach (Legal Research) (Peter Mahmud Marzuki, 2014) elections, election disputes and Gakkumdu. The legal materials used by the authors in this study were obtained from the primary law material namely Law Number 7 of 2017 on Elections, KPU Regulations, Court Decisions. Secondary Legal Material is a library material containing information about primary materials, such as Abstracts, Indices, bibliographies, government issuance, and other reference (Soerjono Soekanto, 2018). The collection of legal materials is done by searching the library/digital library through browsing internet. The materials sought in this study are legal materials in the form of Information on the evaluation of the role of Gakkumdu in resolving election disputes in 2019. Materials can produce a conclusion that can be accounted for, then analyzed using descriptive methods of (Peter Mahmud Marzuki, 2017).

\section{Research Results and Discussion}

\section{A. The Problem of Election Disputes in Simultaneous Elections}

Indonesia as a legal country with the highest sovereignty is in the hands of the people, has some juridical implications closely related to elections. This is because the state of law mandates that elections are necessary to ensure 
that the law is made democratically, i.e. by institutions chosen by the people through democratic (Asshiddiqie, 2010). The selection of democratic government organizing organs to ensure the fulfillment of representative elements. Through the election of representatives of the people, the people are being involved in the determination of legislators. Because basically the election is to elect representatives of the people who later carry out the function of legislation, namely as a maker of legal products. Not only that, in relation to the fulfillment of human rights principles, elections seek to accommodate human rights needs, in terms of the right to vote and be elected and equal rights before the law for all citizens (Mahfud MD, 1999).

It should be understood that all democracies that identify themselves as a modern democracy conduct elections but not all elections (Rosana, 2016). Because a democratic election must be competitive, periodic, inclusive (broad) and definitive, namely determining the leadership of the government in the future (Nugraha, 2015). Adam Pzeworski noted, there are at least two reasons why elections become very important variables in a democratic (Ukiyatiningsih, 2018); First, elections are a mechanism for peaceful transfer of political power. The understanding is, the legitimacy of the power of a particular person or political party is not obtained by means of violence, but because it wins most of the popular vote through fair elections. Second, a democracy that provides a space of freedom for individuals, inevitably the occurrence of conflicts. Elections in this context, should institutionalize them especially with regard to seizing and maintaining power so that the conflicts are resolved through existing democratic (Yogyakarta, 2016).

In short it can be understood that democracy will not come, grow and develop by itself in the life of society, state and nation without real efforts of every citizen and supporting device that is conducive culture as a manifestation of a mindset and the design of society. The use of democracy as a way of life in every aspect of state life by both the people and the government. A true democratic political system, the minimum requirement is the existence of a balanced political power of society, in addition to other balance factors, such as ideology, economy, social and (Hidayat, 2012).

As a form of fulfillment of democratic elements, elections must be held (Asshiddiqie, 2009). This is important because there are several factors that influence it, namely: First, people's opinions or aspirations regarding various aspects of national and state life tend to be dynamic. Therefore elections need to be made periodically to accommodate this. Second, in addition to the changing opinion factors of the community, external factors in people's lives are also a consideration. Change can come from international dynamism and other outside factors. it is this change that causes the political climate to be dynamic. Third, changes in the character of voters, such as the emergence of a 
considerable number of novice voters, increased political intelligence and so on. Fourth, elections need to be conducted periodically to provide regeneration at the top of the holder of power. The change of leadership relay baton is expected to change the state of the country. in Indonesia, elections are held periodically every five years (Asshiddiqie, 2009).

Elections can be held with different systems (Al-fatih, 2020). The majority of countries have their own character before deciding to use an electoral system that is suitable for their country. In general, however, there are two electoral systems, the proportional system and the district system. Proportional system is often referred to as multy-member-constituencies system, while district system is also known as single-member-constituency. In a proportional system, one large region selects several representatives whose numbers are determined based on the balance of population. While in the district system, one district (small area) chooses one representative on the basis of plurality (Al-fatih, Safaat, \& Dahlan, 2014). Indonesia since the 2004 legislative elections, has adopted a proportional system of open lists and a largely representative district system.

The organs of election organizers in Indonesia consist of the Electoral Commission $(K P U)$, the Election Supervisory Board (Bawaslu) and the Honorary Board of Election Organizers (DKPP). Especially for the implementation of elections in 2014, the regulation is regulated in Law No. 8 of 2012 on The Election of Members of the DPR, Provincial DPRD, Regency/City DPRD and DPD. As for the implementation of elections in 2019, the regulation is regulated in Law Number 7 of 2017 on Elections.

The 2019 elections were successfully held through a coordinated regulation, namely Law Number 7 of 2017 on Elections (hereinafter referred to as the Election Law). Although successfully codified in the form of the Electoral Law, but technically the implementation is not good enough. This is evidenced by the number of cases and disputes that accompanied the holding of simultaneous elections in 2019 (Nasution, 2019). The emergence of election disputes, especially in the implementation of simultaneous elections, is at least triggered by stakeholders or the main elements of elections, namely: the Government, Election Participants and Election (Wilar, 2019). All three, in the event of ineffectiveness or conflict, it is possible to open election disputes and add to the long list of homework of Election law enforcement, especially with regard to electoral crimes.

Topo Santoso mentioned that in order to protect the purity of elections from fraud, lawmakers categorize such fraudulent acts as criminal (Santoso, 2004). Thus, it can be interpreted that electoral crimes are all forms of sanctions imposed due to fraud that occurs during the election process. Topo Santoso also mentioned that there has been an increase in developments in electoral 
crimes that include the wider scope of electoral crimes, an increase in the types of criminal acts and an increase in criminal (Ersan \& Erliyana, 2018). Almost in every election period, always tinged with electoral crimes, including the simultaneous elections in 2019.

It is also supported by data, that there has been an increase in the number of cases or disputes elections from 2014 and 2019. Specifically for criminal violations, in the 2014 elections there was only one case whose case was examined and decided by the court, while in the 2019 elections the alleged crimes examined and decided by the court reached 17 (Fahmi, Amsari, Azheri, \& Kabullah, 2020). The increase in the number of disputes, can be interpreted as the increasing complexity of organizing elections, especially carried out simultaneously. This condition is prone to result in the number of cases that are not completed until the verdict is in-kracht. In fact, the issue of law enforcement in elections in general covers three different legal domains, namely: Disputes of results resolved in the Constitutional Court, Settlement of electoral criminal cases resolved through the District Court, Settlement of administrative violations committed by the Electoral Commission, Provincial Election Commission, District/City based on the report Bawaslu and Panwaslu (Saragih, 2017).

The condition is exacerbated by the ineffectiveness of election law enforcement regulations, among others contained in the Election Law with Bawaslu Regulation, In Article 486 of The Third Section of the Election Law that discusses the Integrated Law Enforcement Center (Sentra Gakkumdu), it is mentioned that The Gakkumdu Center is attached to Bawaslu, Bawaslu Province and Bawaslu (Indonesia, 2017). In Article 486 paragraph (11) of the Election Law it is stated that further provisions on Sentra Gakkumdu are regulated by the Bawaslu Regulation. While in Article 487 paragraph (1) and (2) it is mentioned that the Bawaslu Regulation governing the Sentra Gakkumdu is compiled jointly by the Police Chief, the Attorney General of the Republic of Indonesia and the Chairman of Bawaslu considering the results of the Hearing Meeting (RDP) with the DPR.

The mandate of the Election Law to make Bawaslu Regulation immediately responded with the ratification of Bawaslu Regulation No. 31 of 2018 on Integrated Law Enforcement Centers (hereinafter referred to as Perbawaslu Sentra Gakkumdu) (RI, 2018). Technically, Sentra Gakkumdu is regulated in the Perbawaslu Sentra Gakkumdu, which states that the handling of electoral crimes is carried out one stop by Gakkumdu. Based on two related regulations, both the Election Law and perbawaslu Sentra Gakkumdu, found ineffectiveness in the implementation of Gakkumdu in several ways, such (Junaidi, 2020) : 
1. Regulatory problems that require that Gakkumdu decision must be unanimous among institutions incorporated in the center Gakkumdu

2. Dissenting opinion is only a record in decisions;

3. Prosecutors and investigators including police investigators who are members of Gakkumdu are still charged with the work responsibilities of their respective agencies so as not to run optimally;

4. Bawaslu authority that should have a central position will be aligned with other institutions (prosecutors and police).

Derogation of Bawaslu authority in Sentra Gakkumdu as a person contained in Perbawaslu Sentra Gakkumdu, not in accordance with the mandate in the Election Law. In fact, related to Gakkumdu budget, the Election Law in Article 486 paragraph (9) states that gakkumdu operational budget is charged to Bawaslu. Thus, there will be many institutions that deal with electoral crimes, with overlapping authorities and regulations. The Constitutional Court, the Indonesian Police, the Attorney General's Office, the District Court, the KPU, Bawaslu and Panwaslu are different institutions. These institutions may interpret and provide legal certainty in accordance with their competence, but it is very vulnerable to be able to fulfill the meaning of substantive justice. Indonesia, in the context of disputes and enforcement of election law, needs to immediately have an integrative institution and be able to resolve election disputes from upstream to downstream.

\section{B. Conceptualization of Integrated Law Enforcement Agencies in Resolving Election Disputes}

Simultaneous elections in 2019 in selecting members who sit as members of the legislature and executive in practice have several disadvantages (Solihah, 2018). One of them is the pattern of resolution of both violations and election disputes. There are several institutions that have authority in resolving disputes or election violations. Such as Bawaslu (Board of Election Supervisors), nomination disputes in the State Administrative Court (PTUN), disputes of results in the Constitutional Court $(M K)$, if related to criminality become the territory of the authority of the District Court $(P N)$, the Honorary Board of Election Organizers (DKPP) and the Supreme Court (MA) (Aermadepa, 2019)

If the nomination of regional head election participants by Bawaslu Province/District or City Election Supervisory Committee is completed gradually or in stages. After going through Bawaslu or Panwaslu Regency/City, delegated to PTUN until the final effort is the law of cassation to the MA. This paper is more focused on the analysis of the settlement of criminal violations in 
the District Court (PNP) involving Gakkumdu. As described above in the practice of dispute resolution process or violations exist in some institutions.

In the event of an election dispute, Bawaslu is domiciled as the first institution whose task is to mediate. If agreed, the Bawaslu Verdict will be issued, if no agreement is reached then continue the court proceedings. Gakkumdu was originally established to deal with election-related violations or crimes. The coordination pattern is built by including police and prosecutors at all levels both in the province and at the district/city level. The investigators and prosecutors formed are in Bawaslu coordination and are ad hoc.

In the book of one chapter the general provisions of the term Gakkumdu are laid the legal basis. Written in Article 1 paragraph 38 which reads Integrated Law Enforcement Center hereinafter called Gakkumdu is the center of election criminal law enforcement activities consisting of elements Bawaslu, Bawaslu Province, and/or Bawaslu Regency/City, The National Police of the Republic of Indonesia, Regional Police, and/or Resort Police, and the Attorney General of the Republic of Indonesia, the Attorney General, and/or the State Prosecutor.

The problem is related to the performance of Sentra Gakkumdu (Integrated Law Enforcement) itself. Differences in perception in the implementation stage can be prepared by holding various discussion forums in achieving equality of understanding of the handling of electoral crimes as well as evaluation of regulatory weaknesses. Although in the 2019 elections the number of cases indicated as election violations as many as 2724 cases and the tendency of the number of those who continued to come out verdicts in-kracht (permanent legal force) that reached 320 cases or about $9 \%$ only But if identified further than the number of reports above that continued to the investigation stage there are 582 or 17\% (Tumpal HS, 2019). Stopped at the investigation stage of 132 cases, and stopped at the prosecution stage of 41 cases. The total number of cases that stopped in the discussion of the two was up to 62\% (Tumpal HS, 2019).

From the data on the number of cases of electoral crimes nationally, the author tries to take the example of electoral crimes from Aceh Province. Aceh province, there were 164 cases of simultaneous electoral crimes in 2019 with details of violations of Article 490, Article 491, Article 494, Article 504, Article 505, Article 510, Article 516, Article 521, Article 523 paragraph (1), (2), (3), Article 532, Article 533, Article 537 and Article 551 (Din, Rizanizarli, \& Jalil, 2020). The majority of cases of electoral crimes in Aceh Province are related to campaign violations, loss of votes and increased candidate votes (Din et al., 2020). Each of these cases is resolved through the Gakkumdu Center in accordance with the mandate in the Law on Elections and Perbawaslu Sentra Gakkumdu. Gakkumdu as mentioned earlier, consists of Bawaslu, Police and Prosecutors. 
In practice, three institutions that simultaneously become the driver Gakkumdu is in many cases there is no understanding of the perception of Bawaslu, police, and prosecutors simultaneously in handling electoral criminal cases. Other examples such as the campaign outside the schedule element is clearly sounded there must be a decision $K P U, K P U$ province, and KPU district/city that is cumulative because it uses the word 'and'. It means that at the same time, there must be a hierarchy across the organizers that forms decisions about the campaign schedule in the media. Whereas we know, there was never a decision KPU about the campaign schedule in the mass media. This, raises dissent. Also, related to election criminal hand-caught operations (OTT) conducted by the police in several places. Bawaslu himself does not know OTT, but only findings or reports. Prevention and supervision functions are an integral part of the handling of electoral crimes.

Electoral crimes are processed through the criminal justice system, namely through the Police, Prosecutors, and Courts. Criminal sanctions are the harshest so that only the state through the Court can drop witnesses for the perpetrators of electoral crimes. This contrasts with administrative sanctions in which governments or state institutions such as the Electoral Commission are authorized to impose administrative sanctions, without going through a judicial process. Therefore, if any election participant commits administrative violations, the Electoral Commission or the Regional Election Commission who get forwarding reports or findings from the Election Supervisor, can process and impose administrative sanctions on such violators. So, to streamline the handling of electoral crimes related to criminal matters, Bawaslu, Police, and Prosecutors form an Integrated Law Enforcement Center hereinafter abbreviated as Gakkumdu. Membership of the Integrated Law Enforcement Center at the central level consists of Kabareskrim Polri, The Young Attorney General of General Crime, and the Head of The Handling of Election Violations Bawaslu. At the Provincial level, it consists of the Director of General Criminal Investigation, Assistant General Criminal Chief Prosecutor, Coordinator of Legal Affairs and Handling of Election Violations Panwaslu Province.

The importance of integrated Law Enforcement Center in handling Legislative Election Crimes in 2019 is to receive reports of criminal acts of legislative elections in 2019 from Bawaslu and or Panwaslu. Technically, the Integrated Law Enforcement Center conducts research and assessment through the mechanism of the title of the case of each election crime report received from Bawaslu and or Panwaslu.

Understanding between agencies that intersect their authority in one container namely Gakkumdu is needed the same understanding in the application of elements of electoral crimes between Bawaslu, police and prosecutors 
(FEBRIAN SAFITRI, 2019). Another problem that is very possibles arises, namely technically the existence of several provinces/districts/cities that do not have Polda/Polres and or Kejati/Kejari so that there are constraints in coordination with the Polda/Polres and or Kejati/Kejari in the main area. The state of facilities and infrastructure that are not the same in each region can also cause obstacles in its implementation.

Integrated Law Enforcement Center is the beginning of the handling of electoral crimes that determine the direction and objectives of reports and alleged electoral crimes, therefore the Integrated Law Enforcement Center is expected to work effectively and efficiently so that the objectives can be achieved. If you look at the duties and functions of the Integrated Law Enforcement Center that is very serious, therefore, it is necessary to take the seriousness of Law Enforcement in handling it, as stated by Soerjono Soekanto that law enforcement actually lies in the factors that (Soekanto, 2019). Those factors are the legal factors themselves, law enforcement factors, facilities and infrastructure factors, community factors and cultural factors. The most important factor that influences is consistency in the enforcement of election rules.

As an effort to strengthen Gakkumdu institutions and consistency in the enforcement of election rules, the authors try to provide a comparison study of several institutions or efforts to resolve electoral disputes abroad. For example, in Brazil the electoral dispute is the authority of the Superior Electoral Court(TSE) (Satriawan, Wijayanti, Prastanta, \& Rahman, 2015). The TSE has jurisdiction over all aspects of the election and regulates the functioning of political parties. Its authority includes overseeing party conventions and internal elections, approving or cancelling party registrations, registering candidates and authorizing those elected, regulating and supervising the party's access to nonpaid time access on television and radio during elections, and registering voters.

Brazil's Constitution regulates very specifically about the composition of the(Satriawan et al., 2015). There are seven judges, three judges are selected from members of the Federal Supreme Court, two judges are selected from members of the Superior Court of Justice, and two judges are nominated by the president, who are selected among six legal practitioners who are well known for their legal knowledge and have a good moral reputation appointed by the Federal Supreme Court, to maintain the non-political character of the electoral court, the judges served for a period of two years and were unable to serve more than two consecutive terms (Satriawan et al., 2015).

While in Uruguay, the Electoral Law of 1924 established an autonomous, independent and permanent electoral body (Satriawan et al., 2015). Elections are held under the jurisdiction of the Corte Electoral Court. In 1934, the existence and 
power of the electoral court was declared in the constitution. The membership of the court is mixed (Sapto Hermawan, 2019: 10), with five "politically impartial" members all elected by the legislature, and four representatives from political parties with the most votes voted by members of each party in the legislature. There are similarities between electoral dispute resolution institutions in Brazil and Uruguay, which is a permanent form of institution. Unfortunately, Gakkumdu in Indonesia is not a permanent institution, so its authority is less able to cover comprehensively from upstream to downstream in the efforts to enforce electoral law.

A firm stance aimed only at the beginning, or against some parties only, or in certain areas, will only make the public disrespectful and cynical about the enforcement of electoral law. Of course, this is very dangerous because the quality of elections can be greatly reduced and degraded. Therefore, the first step of the election supervisor in bringing cases of fraud to law enforcement is a good first step that must be followed by similar steps consistently and continuously from various parties. Nevertheless, to strengthen the institutional and function of Gakkumdu, it is important to make changes to the Election Law by strengthening and institutionalizing Gakkumdu. The revision relates to the main role of Gakkumdu which is expected to become a permanent institution to resolve election disputes from upstream to downstream, such as the KPK's authority in eradicating corruption.

\section{Conclusion}

The issue of dispute resolution and election violations in Indonesia has many fundamental issues. In principle, the problem occurs because of the lack of the same pattern of settlement between institutions that have authority in dispute resolution and election violations. Gakkumdu which was formed as a law enforcement center consisting of the Police, prosecutors under the coordination of Bawaslu is not effective enough in the settlement of existing elections. Gakkumdu needs to be used as a permanent institution that has the authority of election law enforcement from upstream to downstream in an integrated manner through institutional strengthening Gakkumdu.

\section{Acknowledgments}

The author thanked the Faculty of Law of Muhammadiyah University Malang (UMM) for their support and support. Also, to the sponsor, DPPM UMM who has passed this research proposal until finally fruitful work into scientific articles. Hopefully useful. May Allah bless us. 


\section{BIBLIOGRAPHY:}

\section{Books:}

Asshiddiqie, J. (2009). Menuju Negara Hukum yang Demokratis. Jakarta: Gramedia Pustaka Utama

Asshiddiqie, J. (2010). Konstitusi Ekonomi. Jakarta: Kompas.

Aziz Hakim, A. (2011). Negara Hukum dan Demokrasi di Indonesia. Yogyakarta:

Pustaka Pelajar.

FEBRIAN SAFITRI, E. (2019). ANALISIS PERAN SENTRA PENEGAKAN HUKUM

TERPADU (GAKKUMDU) DALAM PENANGGULANGAN TINDAK PIDANA

PEMILIHAN KEPALA DAERAH (Studi Pada Provinsi Lampung). Unila.

Hadya Jayani, D. (2019). MK Tangani Ribuan KasusSengketa Pemilu sejak 2004.

Hidayat, I. (2012). Teori-Teori Politik. Malang: Setara Press.

Soekanto, S. (2019). Faktor Faktor yang Mempengaruhi Penegakan Hukum. Jakarta:

Rajagrafindo Persada.

Soerjono Soekanto. (2018). Penelitian Hukum Normatif: Suatu Tinjauan Singkat. In Rajawali Press. Jakarta: Rajawali Press.

Mahfud MD, M. (1999). Hukum dan Pilar-Pilar Demokrasi. Yogyakarta: Gama Media. Peter Mahmud Marzuki. (2014). Penelitian Hukum. Jakarta: Kencana Prenada Media Group.

Peter Mahmud Marzuki. (2017). Penelitian Hukum: Edisi Revisi (Cetakan ke).

Retrieved from

https:/ / books.google.co.id/books?id=CKZADwAAQBAJ\&printsec $=$ frontcov er\&dq=Marzuki,+Peter+Mahmud,+(2014),+Penelitian+Hukum,+Cetakan+ke9,+Jakarta:+Kencana+Media+Group.\&hl=id\&sa=X\&ved=0ahUKEwiNlijqlbTp AhXWWisKHWktCXAQ6AEIMjAB\#v=onepage\& $q \& \mathrm{f}=$ false

Satriawan, I., Wijayanti, S. N., Prastanta, L. D., \& Rahman, R. A. (2015). Reformasi Model Penyelesaian Sengketa Pemilukada di Indonesia. Retrieved from https:/ / scholar.google.co.id/scholar?hl=id\&as_sdt=0\%2C5\&q=penyelesaian+ sengketa + pemilu+di+malaysia\&btnG $=$

Salabi, A. (2019). Perludem Rekomendasikan Perbaikan Penegakan Hukum Pidana Pemilu.

\section{Journals:}

Aermadepa. (2019). Penyelesaian Sengketa Proses Pemilu Oleh Bawaslu :

Tantangan dan Masa Depan. Justitia: Jurnal Ilmu Hukum Dan Humaniora, 1(2), 1-14. Retrieved from http:/ /jurnal.umtapsel.ac.id/index.php/Justitia/article/view/974/665

Al-fatih, S. (2020). Electoral Regulation in Indonesia : Is It Modern Law ? Unnes Law 
Journal, 6(2), 205-216.

https:// doi.org/https:// doi.org/10.15294/ulj.v6i2.41627

Al-Fatih, S. (2019). Akibat Hukum Regulasi tentang Threshold dalamPemilihan

Umum Legislatif dan Pemilihan Presiden: Kajian Putusan Mahkamah

Konstitusi Nomor 52/PUU-X/2012 dan Nomor 14/PUU-XI/ 2013. Jurnal

Yudisial, 12(1), 17-38. https://doi.org/10.29123/jy.v12i1.258

Al-fatih, S., Safaat, M. A., \& Dahlan, M. (2014). Reformulasi Parliamentary

Threshold Yang Berkeadilan Dalam Pemilu Legislatif Di Indonesia. Jurnal

Hukum, 20. Retrieved from

http://hukum.studentjournal.ub.ac.id/index.php/hukum/article/view/1018 /1007

Din, M., Rizanizarli, R., \& Jalil, A. (2020). Model Penegakan Hukum Tindak Pidana

Pemilu di Provinsi Aceh yang Berkeadilan. Jurnal Penelitian Hukum De JureDe Jure, 20(3), 289-300.

https:// doi.org/ttp://dx.doi.org/10.30641/dejure.2020.V20.289-300

Ersan, P., \& Erliyana, A. (2018). KUALIFIKASI HUKUM PIDANA KHUSUS

TERHADAP TINDAK PIDANA PEMILU/PILKADA (Tinjauan Hukum

Administrasi Negara). Palar | Pakuan Law Review, 4(1), 1-23.

https:// doi.org/10.33751/palar.v4i1.781

Fahmi, K., Amsari, F., Azheri, B., \& Kabullah, M. I. (2020). Sistem Keadilan Pemilu dalam Penanganan Pelanggaran dan Sengketa Proses Pemilu Serentak 2019 di

Sumatera Barat. Jurnal Konstitusi, 17(1), 001. https:// doi.org/10.31078/jk1711

Fatih, S. Al. (2020). PENERAPAN THRESHOLD DALAM PEMILU. Audito

Comparative Law Journal, 1(2), 78-84.

https://doi.org/https://doi.org/10.22219/audito.v1i2.13973

Hermawan, S. (2019). Pembabakan Kebijakan Lingkungan Hidup Nasional Berbasis Kearifan Lokal sebagai Strategi Adaptasi Menghadapi Perubahan Iklim. Majalah Ilmiah Cakrawala Hukum, 21(1), 1-11.

Junaidi, M. (2020). PIDANA PEMILU DAN PILKADA OLEH SENTRA

PENEGAKAN HUKUM TERPADU. Jurnal Ius Constituendum, 5(2), 220-234.

https:// doi.org/http://dx.doi.org/10.26623/jic.v5i2.2631

Liando, D. M. (2016). PEMILU DAN PARTISIPASI POLITIK MASYARAKAT

(Studi Pada Pemilihan Anggota Legislatif Dan Pemilihan Presiden Dan Calon

Wakil Presiden Di Kabupaten Minahasa Tahun 2014). Jurnal LPPM Bidang

EkoSosBudKum, 3(2), 14-28. Retrieved from

https:// ejournal.unsrat.ac.id/index.php/lppmekososbudkum/article/viewFi le/17190/16738

Nasution, A. P. (2019). PROBLEMATIKA PEMILIHAN UMUM SERENTAK

TAHUN 2019. Retrieved from

http://artikel.adenasution.com/index.php/artkel/article/view/29/28

Nazir, A. (2017). Pengaruh Tata Kelola Pemilih Terhadap Efektivitas. Jurnal Ilmiah 
Prodi Manajemen Universitas Pamulang, Vol. 4, No(2), 82-97.

https:// doi.org/http://dx.doi.org/10.32493/jk.v4i2.y2017.p\%25p

Nugraha, H. S. (2015). Redesain Kewenangan Mahkamah Konstitusi Dalam

Penyelesaian Sengketa Perselisihan Hasil Pemilihan Umum Presiden Dan

Wakil Presiden Di Indonesia. Jurnal Hukum Ius Quia Iustum, 22(3), 420-441.

https:// doi.org/10.20885/iustum.vol22.iss3.art5

Rosana, E. (2016). Negara Demokrasi Dan Hak Asasi Manusia. Jurnal TAPIs, 12(1), 37-53.

Santoso, T. (2004). PENYELESAIAN TINDAK PIDANA PEMILU DI INDONESIA.

Jurnal Hukum \& Pembangunan, 33(2), 268-281. Retrieved from

http://jhp.ui.ac.id/index.php/home/article/view/1390/1312

Saragih, A. D. A. (2017). TINJAUAN YURIDIS PENTINGNYA PEMBENTUKAN

PERADILAN KHUSUS DALAM PEMILU SERENTAK MENURUT

UNDANGUNDANG PEMILIHAN KEPALA DAERAH. Lex et Societatis, 4(3),

9-15. Retrieved from

https:// ejournal.unsrat.ac.id/index.php/lexetsocietatis/article/view/15590/ 15127

Solihah, R. (2018). Peluang dan Tantangan Pemilu Serentak 2019 dalam Perspektif Politik. Jurnal Ilmiah Ilmu Pemerintahan, 3(1).

https://doi.org/10.14710/jiip.v3i1.3234

Surbakti, R. et. a. (2011). Penanganan Sengketa Pemilu. Jakarta: Kemitraan bagi Pembaruan Tata Pemerintahan.

Ukiyatiningsih. (2018). PENINGKATAN HASIL BELAJAR PPKn MEWUJUDKAN PRINSIP-PRINSIP KEDAULATAN SESUAI UNDANG-UNDANG DASAR

NEGARA REPUBLIK INDONESIA TAHUN 1945 MATERI

PEMILUMELALUI METODESIMULASI. Jurnal Education and Economics, 01(04), 450-463.

Wilar, W. F. (2019). Stakeholder Pemilu Dalam Menyukseskan Pelaksanaan Pemilu Serentak 17 April Tahun 2019. Jurnal Holistik, 12(0), 1-13. Retrieved from https://ejournal.unsrat.ac.id/index.php/holistik/article/view/23448/23129

\section{Legal Documents:}

Indonesia, R. Undang-Undnag Nomor 7 Tahun 2017 Tentang Pemilihan Umum. , Pub. L. No. 7, 1 (2017).

RI, B. PERATURAN BADAN PENGAWAS PEMILIHAN UMUM REPUBLIK INDONESIA NOMOR 31 TAHUN 2018 TENTANG SENTRA PENEGAKAN HUKUM TERPADU. , (2018).

\section{Internet:}

Yogyakarta, K. DI. (2016). Pengertian, Fungsi dan Sistem Pemilihan Umum. 
Retrieved February 27, 2020, from KPU DIY website:

https://diy.kpu.go.id/web/2016/12/19/pengertian-fungsi-dan-sistempemilihan-umum/

Tumpal HS, R. (2019). Beda Persepsi Gakkumdu, Dewi: Perlu Diskusi Mencari Solusi Kelemahan UU. Retrieved September 20, 2020, from Bawaslu RI website: https:/ / www.bawaslu.go.id/en/berita/beda-persepsi-gakkumdudewi-perlu-diskusi-mencari-solusi-kelemahan-uu

Soedarsono. (2006). Mahkamah Konstitusi sebagai Pengawal Demokrasi. Retrieved from

https://www.google.com/search?safe=strict\&sxsrf=ALeKk02REsQ1H4fEl9eu qFjqoqXmugA-

SQ\%3A1589492419672\&ei=w7q9XtDSKNLn9QP18aaYAg\&q=Soedarsono \%2C $+\% 282006 \% 29 \% 2 \mathrm{C}+\% 22 \mathrm{Mahkamah}+$ Konstitusi+sebagai+Pengawal+Demokra si $\% 22 \% 2 \mathrm{C}+$ Jakarta $\% 3 \mathrm{~A}+$ Sekjen+dan+Kepaniteraan+MKRI.\&oq=Soedarsono\% $2 \mathrm{C}+\% 282006 \% 29 \% 2 \mathrm{C}+\% 22 \mathrm{Mahkamah}+$ Konstitusi+sebagai+Pengawal+Demo krasi\%22\%2C+Jakarta\%3A+Sekjen+dan+Kepaniteraan+MKRI.\&gs_lcp=CgZw c3ktYWIQAzIECAAQRzIECAAQR1CyT1jYamCybGgAcAF4AIABAIgBAJIBA JgBAaABAaoBB2d3cy13aXo\&sclient=psyab\&ved=0ahUKEwiQwLDYqLTpAhXSc30KHfW4CSMQ4dUDCAs\&uact=5 